\title{
AGENTS OF PRODUCING THE URBAN SPACE: A DISCUSSION ABOUT SMALL BUILDERS OF HOUSES
}

agentes que produzem o espaço urbano: discussão sobre pequenos construtores de casa

Tânia Maria Fresca *

\section{Resumo}

O trabalho apresenta uma discussão a respeito do pequeno construtor de casas na cidade de Londrina - PR, a partir dos anos de 1990, colocando-o como um agente da produção do espaço urbano. Este construtor é aquele que atua na legalidade, constrói casas até $80 \mathrm{~m}^{2}$, com recursos próprios para sua comercialização, em diferentes localizações da malha urbana. Tem participado ativamente no provimento da habitação na cidade, mas sua escala espacial de atuação é pequena, se realizando mediante diversas estratégias. Sua presença e importância, têm ratificado a diversidade de agentes da produção do espaço e da casa.

Palavras-chaves: Pequeno construtor; Casas; Agente; Espaço urbano.

\begin{abstract}
This work presents a discussion about builder of houses in the city of Londrina - PR, from the years 1990 becoming an agent of production of urban space. This builder is one that operates within the law, it builds houses until $80 \mathrm{~m}^{2}$, through their own resources for commercialization in different locations of the urban area. He has been actively participated in the provision of habitation in the city, but their spatial scale of operation is small, taking through various strategies. Their presence and importance, has ratified the diversity of agents of the production of space and the house.
\end{abstract}

Key words: Small builder; Houses; Agent; Urban space.

\section{Resumen}

El articulo se presenta una discusión sobre el pequeño fabricante de casas en la ciudad de Londrina - PR, desde los años de 1990, como un agente de la producción del espacio urbano. Este fabricante es uno de los que actúa en la legalidad, construye casas de hasta $80 \mathrm{~m}^{2}$, con recursos propios para su comercialización, en diferentes lugares en el tejido urbano. Ha participado activamente en el suministro de vivienda en la ciudad, pero su escala espacial de las operaciones es pequeño, si se realiza a través de distintas estrategias. Su presencia e importancia, ha ratificado la diversidad de agentes de la producción del espacio y de la casa.

Palabras Claves: Pequeño frabicante; Casas; Agente; Espacio urbano.

(*) Lecturer, Doctor of the Geoscience Department of the State University of Londrina (Universidade Estadual de Londrina) - Rodovia Celso Garcia CID- PR 445, Km 380, Campus Universitário. Londrina - PR - Brazil. CEP: 86.057-970. Tel: (+55 43) 3371-4246 - tania_geografia@yahoo.com.br 


\section{INTRODUCTION}

The production of urban spaces in the Brazilian context continues to be very complex, because articulated in conjunction with developments in the national economy and involves a diversity of real states, agents, practices and strategies. In this context makes sense to outline some indicative elements of the action of the agents who are producing the space.

This work discusses the role of the small builder of homes. This builder works legally using their own resources seeking commercial objectives and generally builds homes which are $40 \mathrm{~m}^{2}$ to $80 \mathrm{~m}^{2}$ in size. This is a "concrete social agent, whose action is complex, deriving from the dynamic of capitalist accumulation, of the changing needs of the reproduction of the relationships of production" (Corrêa, 1989, p. 10), their contradictions and the progress of the social division of labor (Corrêa, 1989, p. 13). Their activity varies in time and space and for this reason this work has as its territorial and chronological focus the city of Londrina -PR in the last twenty years.

The issue of the role of small builders is not a new theme for the existing literature in geography, urban sociology, architecture, engineering and even urban economics. But, generally, these builders are not considered important agents in the production of urban space and the provision of housing. Consequently, this article inserts small builders as agents in the context of Londrina since the 1990s, characterizing their beginnings and their main forms of action including, among other things, the type of property built and the location.

This leads this article to ask the following questions: can small builders contribute in a richer way to the understanding of the production of urban space? Are there any regionally specific aspects to their origin and action? This article is also an invitation for further research to develop more clarity concerning whether the small builder can be an agent of urban space production on a national scale in Brazil.

From a methodological perspective, this work is based on a review of the literature on the production of the city, of urban spaces and the agents who produce them, and on small builders in the Brazilian context. Data regarding the approval of projects and the inspection of concluded works was collected from the Municipal Council of Londrina, while data about Technical Responsibility Annotations- ARTS- of residential works between 49 and $80 \mathrm{~m}^{2}$ built by the same constructor in Londrina were obtained from the Regional Council of Engineering and Agriculture (CREA-PR) in Londrina Region.

Interviews and conversations were held with representatives of the North Parana Civil Construction Trade Association (Sinduscon Norte-PR) in Londrina, at the Architecture and Engineering Club of Londrina (Ceal), and at the Londrina office for engineering and inspection of works receiving credit of the Caixa Econômica Federal bank. The objective of these interviews and conversations was the collection of data and information about small builders.

The choice of the size in meters of the houses to be researched was based on information obtained from civil construction entities and institutions and from small builders themselves, who affirmed that in Londrina, the most frequently constructed size was between 49 and $80 \mathrm{~m}^{2}$. This range includes an important part of the houses built in the city, being those for which finance is made available for families with an income of less than three minimum wages or in the range of three to five minimum wages. According to municipal legislation, in the master plan, the smallest area for plots of land on which building can take place is $125 \mathrm{~m}^{2}$. In other words, the master plan allows a piece of land to be divided up, as long as the minimum size is of $125 \mathrm{~m}^{2}$.

Why focus specifically on houses? Initially, due to the fact that houses correspond to the predominant form of homes in Brazilian cities. In 2010 (IBGE, 2010) houses made up 69.11\% and apartments $28.24 \%$ of the total of private homes in the city of São Paulo; in Londrina these values were $77,82 \%$ and $20.58 \%$ respectively. Note that these are two cities with a strong presence of vertical buildings for residential use; in other cities where the verticalization is less intense, the presence of houses is strongly enlarged. 
At sequence, the construction of houses (uniques or two homes constructed at the same land and sharing the same wall) has not been the focus of attention of the larger construction companies. This is due to the fact that as these houses are located in different places in the urban environment the cost per unit becomes high for a large construction company. In this way, the houses which this present article refers to are those built by the same individual builder who is normally building two, three, or four houses at the same time at different locations in the city.

Interviews were also carried out with different professionals who act in civil construction, such as engineers, architects and site supervisors, among others, to identify small builders. Small builders working in Londrina were interviewed and also those in the cities of Cambé, Ibiporã and Rolândia, located in the wider urban agglomeration of Londrina, to understand their genesis and the characteristics of their action.

This article is divided in three parts, not including the introduction. The first part outlines key elements of civil construction in Londrina in the period of 2003-2013 revealing evidence of the participation of houses in the production of properties. The second part describes the characteristics of this agent in terms of time and space, and the third part discusses small builders and their role in the production of urban space. Finally, some questions for further research are indicated.

\section{ASPECTS OF THE DEVELOPMENT OF CIVIL CONSTRUCTION IN LONDRINA-PR 2003- 2013}

Civil construction has become an important sector in the Brazilian economy in the last years, linked to housing policies implemented by the Federal government since 2003 and intensified after the Programa Minha Casa Minha Vida (My House My Life Program- PMCMV) in 2009. This sector had increasing levels of participation in the GDP and in the basic value added to current prices, reaching 5.8 and 5.7\% for this latter indicator in 2011 and 2012 respectively (IBGE, 2012).

This process also took place in Londrina, with high levels of growth in terms of the proportion of land built upon. Table 1 demonstrates that the evolution of the area of approved projects oscillated between 2003 and 2006, becoming positive until 2013, with the exception of a slight reduction in 2009. The area of works receiving conclusion certificates - necessary to receive a dwelling permit- oscillated considerably in the period studied. This is explained by the fact that larger constructions such as vertical buildings require a longer time to be completed. This is the reason for the area of works receiving conclusion certificates in 2005 being greater than the area of projects being constructed. In this period, the average of certificates was $58.43 \%$ allowing the temporal nature of constructions to be understood and also revealing that a significant number were not carried out, not concluded or had not requested the necessary procedure to receive a dwelling permit. Regarding the last item Abade (2014) makes it clear that between 2004 and 2013 around $75 \%$ of approved projects were issued a dwelling permit upon conclusion.

Table 2 describes the evolution of the total area of projects approved according to the different type of use. Residential use is prevalent with close to $68 \%$, followed by commercial and service use, while industrial use was significantly restricted. One can observe that residential use presented negative oscillations between 2003 and 2006 in terms of total area, after which it was positive, except in the year 2011. Once again it is necessary to remember that the largest projects, especially apartment buildings, are not carried out every year by the same constructors, causing oscillations. Likewise, in 2011 there was some uncertainty in civil construction concerning the start of the President Dilma Rousseff's administration and the continuity of the PMCMV, which stalled the launching of new projects. Commercial and service use represented about $20 \%$ and industrial use $1.4 \%$ of the areas approved between 2003 and 2013. 
Table 1: Londrina - PR - the evolution of the total area of approved construction projects and those receiving a conclusion certificate $\left(\mathrm{m}^{2}\right)$ 2003-2013.

\begin{tabular}{c|c|c|c}
\hline Year & $\begin{array}{c}\text { Approved projects } \\
\left(\mathbf{m}^{2}\right)\end{array}$ & $\begin{array}{c}\text { Conclusion certificates } \\
\mathbf{( m}^{\mathbf{2}}\end{array}$ & $\begin{array}{c}\text { Conclusion certificates/ } \\
\text { Approved projects ( \%) }\end{array}$ \\
\hline 2003 & $689.509,66$ & $493.988,06$ & 71,64 \\
\hline 2004 & $593.445,21$ & $495.314,66$ & 83,46 \\
\hline 2005 & $602.387,38$ & $619.383,57$ & 102,82 \\
\hline 2006 & $524.797,62$ & $297.998,22$ & 56,78 \\
\hline 2007 & $843.651,16$ & $442.019,29$ & 52,39 \\
\hline 2008 & $1.295 .872,23$ & $550.984,78$ & 42,51 \\
\hline 2009 & $1.280 .309,95$ & $519.700,57$ & 40,59 \\
\hline 2010 & $1.431 .420,22$ & $690.536,56$ & 48,24 \\
\hline 2011 & $1.536 .392,13$ & $753.440,30$ & 49,03 \\
\hline $2012 *$ & $1.734 .889,70$ & $798.404,23$ & 46,02 \\
\hline 2013 & $1.894 .556,83$ & $935.023,62$ & 49,35 \\
\hline
\end{tabular}

*This value does not include $936.673,66 \mathrm{~m}^{2}$ which referred to a demolition as these altered the values significantly. Source: Londrina, 2015. Org.: Fresca, T. M.

Table 2: Londrina - PR - evolution of the total area of approved projects by type of use in $\mathrm{m}^{2} 2003-2013$

\begin{tabular}{|c|c|c|c|c|c|}
\hline Year & $\begin{array}{c}\text { Total approved } \\
\text { projects }\left(\mathbf{m}^{2}\right)\end{array}$ & $\begin{array}{c}\text { Residential use } \\
\qquad\left(\mathbf{m}^{2}\right)\end{array}$ & $\begin{array}{c}\text { Commercial } \\
\text { and service use } \\
\left(\mathbf{m}^{2}\right)\end{array}$ & $\begin{array}{c}\text { Industrial } \\
\text { use }\left(\mathbf{m}^{2}\right)\end{array}$ & $\begin{array}{c}\text { Other uses* } \\
\qquad\left(\mathbf{m}^{2}\right)\end{array}$ \\
\hline 2003 & $689.509,66$ & $504.276,04$ & $116.541,42$ & $10.328,94$ & $58.383,26$ \\
\hline 2004 & $593.445,21$ & $362.207,64$ & $124.706,48$ & $21.617,79$ & $85.046,30$ \\
\hline 2005 & $602.387,38$ & $418.148,89$ & $116.344,18$ & $16.544,84$ & $51.349,47$ \\
\hline 2006 & $524.797,62$ & $380.174,72$ & $104.793,96$ & $6.740,53$ & $33.088,41$ \\
\hline 2007 & $843.651,16$ & $623.696,10$ & $146.228,59$ & $14.858,00$ & $58.868,47$ \\
\hline 2008 & $1.295 .872,23$ & $827.574,07$ & $370.079,63$ & $3.200,19$ & $95.018,43$ \\
\hline 2009 & $1.280 .309,95$ & $914.888,98$ & $257.821,18$ & $20.671,33$ & $86.928,54$ \\
\hline 2010 & $1.431 .420,22$ & $1.059 .121,50$ & $189.521,01$ & $12.864,71$ & $169.913,10$ \\
\hline 2011 & $1.536 .392,13$ & $997.965,25$ & $309.261,02$ & $80.183,49$ & $48.982,56$ \\
\hline $2012 * *$ & $1.734 .889,70$ & $1.316 .048,60$ & $299.091,06$ & $8.427,19$ & $111.333,00$ \\
\hline 2013 & $1.894 .556,83$ & $1.095 .185,50$ & $649.561,63$ & $9.120,97$ & $140.688,69$ \\
\hline
\end{tabular}

* Includes schools, health surgeries, other public works, renovations, extensions, demolitions, acoustic isolation, wells, etc. Concerning extensions, these were not included in the residential total as there were no details in the data concerning type of use.

**This value does not include $936,673.66 \mathrm{~m}^{2}$ which referred to a demolition, as these altered the values significantly. Source: Londrina, 2015. Org.: Fresca, T. M.

Table 3 presents a typology of residential uses in Londrina in order to increase understanding of this sector. During this period there were changes in the typology with private condominiums being added in 2007.

The separation between homes with more than $80 \mathrm{~m}^{2}$ and those with less than $80 \mathrm{~m}^{2}$ occurs due to the existing legislation - Resolutions number 262/79 and number 278/83 (CONFEA, 1979 and 1983; BRASIL, 1985) which allow professionals with middle level qualifications in edifications to 
design buildings with up to $80 \mathrm{~m}^{2}$ in total area. It is important to explain that "popular design" is a project developed by CREA-PR in 1989, named Casa Fácil (Easy House) which sought to establish partnerships between professional institutions and municipal governments for the construction of popular houses of up to seventy square meters.

To have access to Casa Fácil, the family income should be of up to three minimum wages and the beneficiary should be able to prove ownership of the land. By federal law 11.888/2008 families which have an income of up to three minimum wages have the right to free public technical assistance for the project and the construction of a social interest habitation for their own dwelling. Thus, the Casa Fácil program [...] allows municipal public administrators to meet this normative demand (CREA-PR, n.p., 2015).

It was a program which avoided homes being built without the required legal regularization by providing help from the municipal government and CREA to supply houses for low income families and which contributed to the public purse through the IPTU (property and urban land tax).

Table 3: Londrina - PR - evolution of residential area $\left(\mathrm{m}^{2}\right)$ and units according to type 2003-2013

\begin{tabular}{|c|c|c|c|c|c|c|c|c|c|c|c|c|}
\hline \multirow[t]{2}{*}{ Year } & \multicolumn{2}{|c|}{$\begin{array}{l}\text { Homes with more } \\
\text { than } 80 \mathrm{~m}^{2}\end{array}$} & \multicolumn{2}{|c|}{$\begin{array}{l}\text { Houses with less } \\
\text { than } 80 \mathrm{~m}^{2}\end{array}$} & \multicolumn{2}{|c|}{$\begin{array}{c}\text { Popular design/ } \\
\text { Casa Fácil }\end{array}$} & \multicolumn{2}{|c|}{ Apartments } & \multicolumn{2}{|c|}{ Housing complex } & \multicolumn{2}{|c|}{$\begin{array}{l}\text { Private condo- } \\
\text { miniums }\end{array}$} \\
\hline & $\mathrm{m}^{2}$ & unid. & $\mathrm{m}^{2}$ & unid. & $\mathrm{m}^{2}$ & unid. & $\mathrm{m}^{2}$ & unid. & $\mathrm{m}^{2}$ & unid. & $\mathrm{m}^{2}$ & unid. \\
\hline 2003 & $202.590,80$ & 1611 & $38.190,42$ & 728 & $21.267,84$ & 326 & $208.817,06$ & 628 & $23.762,83$ & 402 & - & - \\
\hline 2004 & $204.858,66$ & 1221 & $23.068,20$ & 355 & $16.958,50$ & 254 & $94.946,18$ & 316 & $15.297,65$ & 413 & - & - \\
\hline 2005 & $223.029,50$ & 1254 & $22.816,73$ & 369 & $17.447,34$ & 265 & $141.187,68$ & 728 & $8.163,05$ & 27 & - & - \\
\hline 2006 & $157.572,85$ & 938 & $18.885,68$ & 328 & $11.380,52$ & 171 & $185.933,22$ & 369 & $1.394,55$ & 39 & - & - \\
\hline 2007 & $247.153,26$ & 1529 & $33.946,57$ & 525 & $19.946,67$ & 305 & $307.048,03$ & 397 & $5.635,70$ & 194 & 1941,29 & 23 \\
\hline 2008 & $270.428,45$ & 1640 & $38.936,66$ & 581 & $10.327,17$ & 157 & $492.217,35$ & 3359 & 3.68 & 126 & $2.714,44$ & 87 \\
\hline 2009 & $269.086,57$ & 1906 & $37.820,33$ & 646 & $13.100,42$ & 209 & $573.282,71$ & 3008 & $4.291,32$ & 143 & $12.383,63$ & 107 \\
\hline 2010 & $339.984,89$ & 2830 & $72.367,19$ & 1132 & $2.430,68$ & 53 & $487.554,78$ & 4649 & $104.884,53$ & 2132 & $46.607,62$ & 516 \\
\hline 2011 & $269.843,27$ & 2482 & $106.493,27$ & 1586 & $8.859,80$ & 140 & $570.370,35$ & 3451 & 794,26 & 15 & $18.684,11$ & 113 \\
\hline 2012 & $633.711,87$ & 1563 & $77.179,63$ & 1145 & - & - & $350.212,23$ & 2452 & 110,67 & 3 & $32.601,10$ & 152 \\
\hline 2013 & $273.763,69$ & 1942 & $81.911,17$ & 1198 & 139,68 & 2 & $642.903,54$ & 3237 & $87.276,21$ & 1745 & $5.785,27$ & 60 \\
\hline Total & $3.092023,81$ & 18916 & $551.615,85$ & 8.593 & $121.858,62$ & 1882 & $4.054 .473,13$ & 22594 & $255.300,12$ & 5293 & $120.717,46$ & 1058 \\
\hline
\end{tabular}

Source: Londrina, 2015. Org.: Fresca, T. M.

This table reveals that apartments are the largest category in terms of area and number of units, having experienced a sharp increase from 2008, on the eve of the official launch of PMCMV. During this period they represented $32.6 \%$ of the total residential area and $38.76 \%$ of the total of units. From this period onwards, MRV, the large national open capital constructor, began the construction of residential buildings in Londrina targeted at those with incomes in the range of three to ten minimum wages, called the economic segment (Ferreira, 2012). Closed capital constructors based in Londrina, such as Yitcon and Vanguard Home entered this market sector, as did others. The prevalence of apartments in the city is linked to the process of construction of vertical buildings which has been taking place since the 1950s and which has made Londrina one of the most vertical cities in the country (Passos, 2007; Casaril, 2008; Nascimento, 2015).

After this we have houses with more than $80 \mathrm{~m}^{2}$ and houses with less than $80 \mathrm{~m}^{2}$ that represent $24.8 \%$ and $4.4 \%$ of the approved residential area. In terms of units they represent $32.45 \%$ and $14.74 \%$. In contrast, the total referring to popular design (architectural design was prepared by Municipal Council of Londrina and CREA) and housing complex clearly show the weak level of supply until 
2009, when it was expanded through the PMCMV. Even so, housing complex represented only $2.05 \%$ of the total residential areas and $9.08 \%$ of units, and popular design was responsible for $0.98 \%$ of area and $3.22 \%$ of units, while private condominiums were responsible for $0.97 \%$ of area and $1.81 \%$ of units.

These notable elements indicate clearly that in Londrina for the period being considered: a) the supply of houses was concentrated in private enterprises, while the state supply through housing projects was very limited in the light of public policies for the sector; b) even with the PMCMV the supply of housing complex was very restricted when compared to other types, which leads to reflection on the effects of the Program on the access of low income families to housing, so as to reduce the deficit in this income segment. Even when one considers popular design the family still needed to have the private ownership of the land, which continued to express the fundamental conditions of the reproduction of capitalist social relations; c) among all the different types, apartments continue to prevail both in terms of area and the number of units, linked to the strong presence of large constructors and incorporated companies which act in the city. Those with closed capital with headquarters in the city dominate the market, while those of national and international open capital have a more recent activity linked to their recent processes of capitalization with the opening of their capital in the Stock Market and the ease of entry of international capital in the national marketacquiring control over other constructors and incorporated companies - after the implementation of the Financial Estate System in 1997 (Nascimento, 2015); d) houses with more than 80 $\mathrm{m}^{2}$ are the second largest type in terms of the provision of housing. Until 2006, this category would have included those present in condominiums and closed division of land into lots (Lopes, 2009) as well as those in other subdivisions.

From the perspective of job creation, employment in civil construction in Londrina continues to be low. Data from the Work and Labor Ministry (Brasil, 2013) reveals that this sector represented only $5.98 \%$ of the total- 175,265 - of formal jobs in 2013 . However, a part of these jobs were in the service sector, especially activities of hiring temporary and informal labor.

With respect to municipal GDP, Londrina was ranked $45^{\text {th }}$ in the country in 2012 with 12 , $826,470,000$ reais, representing $0.29 \%$ of national GDP, $1.8 \%$ of the GDP of the Southern region and $5 \%$ of the GDP of the state of Parana. In the municipal profile (Londrina, 2014) agriculture has an average participation of $1.77 \%$ between 2003 and 2012, and industry an average of $20.6 \%$ in the same period. Services (which includes commercial activities) represented $66.10 \%$ of the total in 2012 (IBGE, 2015) and administrative activities, health, public education and social security were $10.15 \%$, making the total for services of $76.25 \%$ of municipal GDP.

This process in civil construction has a direct relationship with the macroeconomic policies which were implemented in Brazil from 2003, which allowed a reduction in the level of unemployment, real gains in wages, growth of both GDP and GDP per capita, as well as the increased participation of civil construction in the country's basic added value. Table 4, which provides some indicators of the performance of the Brazilian economy between 2003 and 2013, allows one to perceive that they all experienced positive variation or growth, with the exception of GDP with a negative rate in 2009, linked to the 2008 international financial crisis, as the consequences were felt in Brazil the following year.

From 2011 onwards, one can perceive a reduction in the growth rates of this indicator, linked to the end of a phase of economic expansion. With regards to the participation of civil construction in the gross added value to basic prices, this showed small variations between 2003 and 2008, after which it increased reaching $6.5 \%$ in 2013.

Nonetheless, it is important to emphasize that other macroeconomic measures had a positive effect on the expansion of national civil construction between 2003 and 2013. These include the offer of credit at low interest rates when compared to recent periods, the elimination of taxes on construction materials, and the positive effects of the Programs of Growth Acceleration - PAC 1 
and 2 - which aided the expansion of large construction companies. Circumstances were favorable both for the production and the purchase of properties.

Table 4: Selected indicators of the performance of the Brazilian economy in the period between 2003 and 2013

\begin{tabular}{|c|c|c|c|c|c|}
\hline Year & $\begin{array}{c}\text { Unemployment } \\
\text { rate } \%{ }^{1}\end{array}$ & $\begin{array}{l}\text { Wages with } \\
\text { real increase } \\
\%^{2}\end{array}$ & $\begin{array}{c}\text { GDP annual } \\
\text { variation } \%^{3}\end{array}$ & $\begin{array}{c}\text { GDP per } \\
\text { capita } \mathbf{R}^{4}\end{array}$ & $\begin{array}{c}\text { Participation of civil construction } \\
\text { in Brazil value added to basic } \\
\text { prices } \%^{5}\end{array}$ \\
\hline 2003 & 12,4 & 20 & 1,2 & 9.498 & 4,6 \\
\hline 2004 & 11,5 & 55 & 5,9 & 10.692 & 4,9 \\
\hline 2005 & 9,9 & 72 & 3,2 & 11.658 & 4,7 \\
\hline 2006 & 10 & 86 & 4 & 12.688 & 4,4 \\
\hline 2007 & 9,3 & 88 & 6,1 & 14.465 & 4,6 \\
\hline 2008 & 7,9 & 78 & 5,2 & 16.225 & 4,4 \\
\hline 2009 & 9,1 & 80 & $-0,3$ & 17.196 & 5,4 \\
\hline 2010 & 6,7 & 89 & 7,5 & 19.982 & 6,3 \\
\hline 2011 & 6 & 87 & 2,7 & 22.162 & 6,3 \\
\hline 2012 & 5,5 & 95 & 1 & 23.655 & 6,6 \\
\hline 2013 & 5,4 & 87 & 2,5 & 25.655 & 6,5 \\
\hline
\end{tabular}

Sources: (1) Portal Brasil, 2015; (2) Summa, 2014; (3) Brasil, 2014; (4) IBGE, 2005-2014; (5) Camara Brasileira da Indústria da Construção, 2015.

This general context allowed a greater segmentation in income strata of Brazilian and Londrina families from 2003, according to economic policies implemented by the Lula administration. This had an impact on the consumption potential of families who started to envision the possibility of obtaining their own house. At the same time, income distribution policies, based on the Keynesian actions of the Lula administration, resulted in a greater complexity in the social division of labor and income strata. In this sense a great variety of consumers emerged in the housing market varying considerably in terms of area, location and quality of construction.

\section{THE SMALL BUILDER AFTER 1990}

The first aspect to be discussed is the genesis of the small builder of houses. This generally occurred in the 1990s, in the context of a general weakness of Brazilian housing policy. This weakness was evident in this decade with the general transfer of programs to states and municipalities whose efforts were mainly directed at the middle and lower middle income layers. Of greater importance were programs such as Habitar Brasil (for municipalities with more than 50 thousand people), Morar Município (for smaller municipalities), Pró-Moradia (housing), Credit Letters (FGTS and CEF resources), and the Program for Residential Tenancy. On the whole, the credit offered was reduced in comparison to the previous decade and the housing offered was focused on private supply, while the state's actions did not meet the needs of the population with lower purchasing power (Azevedo and Ribeiro, 1996). In addition, the effects of the Real plan implemented in the 1990s opened people's horizons towards obtaining their own home through the repercussions of the forced control of inflation and the relative stability of prices and salaries. It was in this context that the small builder began to have a greater prominence as there was a demand which was not being met by either the large constructors and incorporated companies or the state.

On the whole the origins of small builder is: a) previous experience as a worker in civil construction, be it as a bricklayer or work supervisor, who has been able to start their activities following the accumulation of a small amount of capital from their work, inheritance, sale of vehicles, land, 
etc. b) workers in commercial or service activities who, through family and personal connections with other small builders started to work in civil construction with modest capital c) small businessmen or industrialists who begun their activity after building their own home for their family.

A recurring fact has been the formation of partnerships between members of the same family and friends, of whom normally at least one has had experience in civil construction.

In any case, those who have remained in the activity have received capacity building to manage and remain in the sector. It is possible to observe that in legal terms many of these builders started their activities in an irregular way and later were able to act according to legal regulations while a very high number of companies only survive for a very short time in this sector.

$\mathrm{He}$ is an agent the may exercise other roles beyond civil construction: he may be a third party contractor (Cardoso, 2013) in civil construction, varying his involvement according to national housing policies. He may diversify his activities by acquiring trucks, setting up a pharmacy or continuing and expanding his involvement in small industries.

In order to be able to act, the small builder needs to possess the private ownership of urban land, guaranteeing one of the foundations for the reproduction of the social relationships of capitalist production. In this sense they are capitalists who normally rely on a small amount of capital for the acquisition of land and the construction of the property while deriving income from the land. For this reason their action will be focused on the sale of the house built so that the profit and income received will be, in part, re-invested in acquiring the next piece of land and the construction of other houses.

This small builder acts according to legal requirements. In other words, they follow Brazilian legislation concerning the construction of a property, legally registering those workers who are hired, making the necessary payments to the INSS and paying municipal taxes. Here two basic situations may emerge: a) the small builder may use their Individual Taxpayer's Registration (CPF) to acquire the land, build the house and pay taxes; b) the small builder may be an individual micro-entrepreneur (MEI) (BRASIL, 2008; BRASIL 2011). In this case as long as their maximum earnings are less than $\mathrm{R} \$ 60.000$ a year and they are neither a partner nor owner of another company they are considered part of the Simples Nacional (National Simple) making a monthly payments of federal taxes. In both cases, the administrative cost for the production of the house is low, as the constructor is responsible for all the activities (hiring those with technical responsibility, paying tributes, hiring workers, acquiring the construction material, etc.). On many occasions these costs are not considered in the full price of the property, only the taxes.

Nonetheless it is necessary to consider that individual micro-entrepreneurs might also have a legally registered employee. During construction more than one worker may be involved either in the whole process or be in specific activities, such as electricians, joiners, tile setter, etc. At the same time it is in these areas where one can often find informal workers in the construction sector, additionally, the builders themselves work directly in the construction without receiving a salary and that would include, where applicable, any partners.

The execution of the work is carried out according to designs and projects. These can be developed by a technician in buildings, which is more common, or by a university trained professional. The work also requires a technician responsible for monitoring according to ART, linked to CREA or to the Brazilian Council of Architects and Urbanism (CAU).

At this stage there is an important social division of labor with various activities being carried out by specialist professionals and companies, such as leveling the ground and laying concrete, revealing the incorporation of modern techniques in the construction process.

The small builder acts in conjunction with the Brazilian property financing system, in the most recent aspects of this public policy. This coordination is fundamental because it allows knowledge of all the different forms of finance available and of the basic rules for each one of its segments. Access to the financial system usually takes place at branches of the Caixa Econômica Federal, in accountancy offices and in offices which work for the CEF, among others. 
As consumers are normally purchasing a house through bank mortgages it is necessary that the house meets basic requirements in terms of construction and pricing. Therefore the small builder needs to know the different levels of property financing in detail.

The small builder also needs to have knowledge of different aspects of the property market. In other words, he needs to have a clear understanding of the market price of properties in the neighborhood where the land on which the house is being constructed is located. This will allow him to decide on the size of the building to be constructed, the standard of finishing and the final price of the house. This is a fundamental element in the process of selling a house to a purchaser who has taken out a bank mortgage, as the appraisal of value to be conducted by the Caixa Econômica Federal or the Bank of Brazil will take the market price into consideration. This means that he cannot build a house which costs more than the value that the market imposes in the neighborhood where the house is located. In the same way, he needs to be aware of the potential customer's income so that the down payment and the installments will be compatible with family income.

From the mid 1990s until 2003, the financing process was very bureaucratic so that the time between starting the process and its conclusion lasted months. This, along with the highest interest rates being charged made it very difficult for the typical consumers of these houses to obtain mortgages. On the whole, consumers would use their FGTS, or money from the sale of their vehicle, motorbike or piece of land to make the initial payment on the house and obtain financing. After 2003, the process for obtaining finance became more agile, less bureaucratic and after 2009 started to receive state subsidies.

The area of the houses built by small builders varies over time. From the mid 1990s until 2005, the houses were normally between 70 and $80 \mathrm{~m}^{2}$ and there would be one house on each piece of land. From then onwards the area was reduced so that those which were $49 \mathrm{~m} 2,54 \mathrm{~m} 2$ and $70 \mathrm{~m}^{2}$ began to dominate, as their prices enabled prospective consumers to obtain finance. At the same time, so as to make the business viable in response to the increasing price of urban land, the construction of multiple houses (two) on plots of $250 \mathrm{~m}^{2}$ expanded.

The standard of finishing on these properties is also varied, tending to be of low or average quality, depending on the location, the price paid for the land, the final sale price of the property and the level of profit the builder is seeking. Common ways of reducing the cost of construction include: a) using ceramic tiles of a low normal PI (abrasion indicator) standard; $b$ ) reducing the size of the load panels (QDF), placing a lower quantity of circuit breakers, not separating the circuits adequately; c) producing the structure and tiles in a way that opts for fascia with a parapet roof in fiber cement and or impermeable slabs; d) using casings (doors and windows) with tempered glass, without mounts and frames, among others.

The location of these houses has followed three recurrent patterns. The first is building in consolidated subdivisions, with the presence of infrastructure, high occupation but with land which has not been built on. On the whole these sites are located between the extreme outskirts and the city center. This is a wide area as it is the availability of the land and price which are the most important factors for small builders. The second are older housing complex, which have existed for about 20 to 30 years. In this case various elements are involved, such as the fact that the house has not undergone significant renovations and extensions, the willingness of the owner to acquire a new home and more importantly, that the size of the land is equal to or above $250 \mathrm{~m}^{2}$. If at least the second and third conditions are satisfied the small builder constructs two houses on the land, one for the owner of the previous house and the second for the builder. These housing complex are located in all the areas of the city of Londrina. However, due to the time they have been in existence, these areas are well consolidated in terms of occupation, infrastructure and the presence and access to collective services, commerce and other small-scale service providers. The third pattern is found on the extreme outskirts of the city, on new sites which have transformed the land use from rural to urban on the edges of the city sprawl. The small builder acquires land with an average of $250 \mathrm{~m}^{2}$ 
directly from the developer and builds houses. On the whole these are sites with the minimum infrastructure and access to public transport demanded by legislation.

Considering that Londrina is the main city of an urban agglomeration that also includes Cambé, Rolândia, Arapongas, Ibiporã and Jataizinho, the neighborhoods between these cities have been one of the areas with a strong presence of small builders in the manner explained above. Another important aspect is the significant increase in land prices since 2009, which has encouraged a greater territorial dispersal in the work of these builders, even involving the extreme outskirts, on sites aimed at the population with a low purchasing power.

Concerning these very high levels of increases in the price of land it is important to explain that land ownership comes with the expectation of a nominal or real increase in its price. At the same time, it "configures an investment with reduced maintenance costs, high potential profitability, and high liquidity, as there is no obstacle to direct transfer" (Gonçalves, 2011, p. 12). Therefore, in conditions where there was a high demand for land for the reasons indicated above, the expectation that there would be an income from land increased both in the expansionary and recessionary phases of the Brazilian economy, leading to the significant increase in the price of land, far above what would be typical for a property investment. Rangel (2005) calls this expectation regarding the increase in the price of land the fourth income which "adds on to others, if they exist, and given that the price of the land is a direct function of total income, this price can become greatly distant from what would result from stricto sensu capitalization" (Rangel, 2005, p. 94).

In the current context, the market for this type of property generally consists of families with an income of up to three minimum wages and between three and five minimum wages, which allows them to pay the installments on the property and receive some form of subsidy. Two strategies have been used to achieve the latter objective: the constructor reduces the price of the property as stipulated in the financing contract and the consumer pays the difference between the real price and the one stipulated in the contract separately. In this case the difference may be between 15 to $20 \%$ depending on the assessment certificate. A second way of facilitating the sale and obtaining a subsidy for the consumer has been to decrease the family income, by one family member choosing to be made redundant.

This is a very large consumer market as the households with an income between two and five minimum wages represented $39.5 \%$ of the Londrina total in 2010 (IBGE) as shown in table 5. Obviously this does not cover the whole consumer market for the houses being discussed but it is possible to get an approximate idea of the potential that this segment represents.

Table 5: Londrina - PR: Total of permanent households in the municipality according to monthly income 2010.

\begin{tabular}{c|c}
\hline Total Permanent Private households & 164.898 \\
\hline Households without income & 3.632 \\
\hline Households with up to half a minimum wage & 1.406 \\
\hline Households with between a half and one minimum wage. & 8.995 \\
\hline Households with more than one and up to two minimum wages & 24.022 \\
\hline Households with more than five and up to ten minimum wages & 65.298 \\
\hline Households with more than ten and up to twenty minimum wages & 16.951 \\
\hline Households with more than twenty wages & 7.608 \\
\hline
\end{tabular}

Source: IBGE, 2010. Org. Fresca, T. M.

Another aspect refers to identifying the participation of these houses in the residential total. This is a difficult procedure given the difficulty of obtaining data from public organizations and professional institutions, and even from fieldwork. Moreover, Table 6 reveals that of the residential projects approved per area and per unit between 2003 and 2013, those homes with less than $80 \mathrm{~m}^{2}$ represented an average of $15.45 \%$ of the total units in the city. 
Table 6: Total of approved projects according to residential use and the participation of homes with less than $80 \mathrm{~m}^{2}$ in Londrina - PR 2003-2013

\begin{tabular}{|c|c|c|c|c|c|}
\hline \multirow[b]{2}{*}{ Year } & \multirow{2}{*}{$\begin{array}{c}\text { Total approved } \\
\text { projects. } \mathbf{m}^{2}\end{array}$} & \multicolumn{2}{|c|}{ Residential total } & \multicolumn{2}{|c|}{ Houses with less than $80 \mathrm{~m}^{2}$} \\
\hline & & $\mathrm{m}^{2}$ & $\begin{array}{c}\text { Number of } \\
\text { units }\end{array}$ & $\begin{array}{c}\% \text { area } / \text { residential } \\
\text { total }\end{array}$ & $\begin{array}{l}\% \text { unit/ resi- } \\
\text { dential total }\end{array}$ \\
\hline 2003 & $689.509,66$ & $202.590,80$ & 1611 & 7,57 & 19,7 \\
\hline 2004 & $593.445,21$ & $204.858,66$ & 1221 & 6,36 & 13,87 \\
\hline 2005 & $602.387,38$ & $223.029,50$ & 1254 & 5,45 & 13,96 \\
\hline 2006 & $524.797,62$ & $157.572,85$ & 938 & 4,96 & 17,77 \\
\hline 2007 & $843.651,16$ & $247.153,26$ & 1529 & 5,44 & 17,65 \\
\hline 2008 & $1.295 .872,23$ & $270.428,45$ & 1640 & 4,7 & 9,76 \\
\hline 2009 & $1.280 .309,95$ & $269.086,57$ & 1906 & 4,13 & 10,73 \\
\hline 2010 & $1.431 .420,22$ & $339.984,89$ & 2830 & 6,83 & 10 \\
\hline 2011 & $1.536 .392,13$ & $269.843,27$ & 2482 & 10,67 & 10,36 \\
\hline 2012 & $1.734 .889,70$ & $633.711,87$ & 1563 & 5,86 & 21,54 \\
\hline 2013 & $1.894 .556,83$ & $273.763,69$ & 1942 & 7,47 & 14,63 \\
\hline
\end{tabular}

Source: Londrina, 2015. Org.: Fresca, T. M.

In terms of area, the participation of these properties in the residential total was an average of $6.31 \%$ during this period. But these numbers do not effectively reveal the participation of the houses produced by many small builders, because these include those built through self-construction and self-enterprise. However, interviews carried out with those linked to professional institutions indicate that the participation of small builders may account for $60 \%$ of the properties in this area range in Londrina. Therefore, small builders built 5.155 homes in the period considered, equivalent to $8.8 \%$ of the residential total.

The final aspect refers to the number of units produced individually by these small constructors. Yearly, this is normally a low figure, oscillating according to the housing policy in place. Hence, from the mid 1990s to 2003, this amount tended to be around one house a year. From then on, it started to increase in the context of the implementation of the Lula administration's housing policy, through the creation of the Ministry of Cities; more resources for property financing; the creation of the National System of Social Interest Housing (SNHIS) and the creation of the National Social Interest Housing Fund (FNHIS) in 2005, among others (Shimbo, 2010). In this new context, the construction of homes reached about four a year and from 2009 onwards increased further. With a greater supply of credit, lower interest rates, and the reduction of the IPI on construction materials the production of houses oscillated between four and at the most twenty houses a year. This number was achieved by only one builder, while the rest of the interviewees remained at the level of four to eight a year. If individually they construct few houses, together they account for a considerable proportion of those homes with less than $80 \mathrm{~m}^{2}$ in Londrina.

Table 7 shows a number of ARTs (Technical Responsibility Annotations) from these same contractors for houses between 49 and $80 \mathrm{~m}^{2}$ according to the number of houses constructed per year between 2008 and 2014. The range of one to four houses a year represented the largest portion and had important growth until 2011, after which it was reduced. The other ranges accounted for a lower proportion and had similar behavior to the first. The table also indicates the presence of small builders building up to 20 houses a year. 
Table 7: Londrina - PR: number of ARTs from the same contractors according to the number of houses constructed a year between $49 \mathrm{~m}^{2}$ and $80 \mathrm{~m}^{2}$ in the period of 2008 to 2014 .

\begin{tabular}{c|c|c|c|c|c}
\hline Year & $\begin{array}{c}\text { Total } \\
\text { ART's }\end{array}$ & $\begin{array}{c}\mathbf{1} \text { to } 4 \\
\text { houses }\end{array}$ & $\begin{array}{c}\mathbf{5} \text { to 8 } \\
\text { houses }\end{array}$ & $\begin{array}{c}\mathbf{9} \text { to 12 } \\
\text { houses }\end{array}$ & $\begin{array}{c}\mathbf{1 3} \text { to 20 } \\
\text { houses }\end{array}$ \\
\hline 2008 & 522 & 478 & 0 & 0 & 44 \\
\hline 2009 & 895 & 798 & 47 & 12 & 38 \\
\hline 2010 & 1645 & 1281 & 225 & 24 & 115 \\
\hline 2011 & 1716 & 1433 & 182 & 83 & 18 \\
\hline 2012 & 507 & 464 & 33 & 10 & 0 \\
\hline 2013 & 436 & 402 & 25 & 9 & 0 \\
\hline 2014 & 344 & 339 & 5 & 0 & 0 \\
\hline
\end{tabular}

Source: CREA-PR, Regional Londrina, 2015

If one takes into account the number of residential projects approved by the city hall of Londrina, which reached a total of 2731 in 2013, and consider the total of ARTs in the range of one to four houses by the same contractors in the same year, one reaches $14.71 \%$ of the municipal total. This number increases to $15.96 \%$ if one considers all the ranges per contractors present in table 7 . Although these are separate sources it is necessary to consider that ARTs are only emitted when these projects are submitted to the municipal government, and therefore these two sources work together formally.

These numbers provide evidence of the high participation of houses with an area between 49 and $80 \mathrm{~m} 2$ in Londrina and prove that in this range there is a high number of contractors, which in part reflects individual small builders.

\section{KEY POINTS FOR DEVELOPING AN UNDERSTANDING OF THE SMALL BUILDER}

There have been recurrent references to small builders in academic literature, indicating their action as agents of production of urban space (Limonad and Barbosa, 2003) at different moments in time (Ribeiro, 1991); as small constructors of buildings (Almeida, 1983; Zacchi 2014); introducing some of the strategies of their activity (Campos et al ,2014), among others.

However, there has not been recent research into their effective characterization, the spatial practices they carry out, the strategies they adopt and into identifying their importance in the production of urban space. It is evident that there is a difficulty in obtaining data for this purpose, especially in large cities. For this reason it is necessary to discuss aspects for developing an understanding of the presence and action of small builders of houses.

In the Brazilian context, where there is a diverse range of urban settlements with different specific characteristics, this leads to marked regional differences and inequalities regarding the participation of small builders in the territorial division of labor and their family incomes. Hence, it is important to develop ways of better understanding these agents and the importance of the scale of their actions and strategies to comprehend the complexity of the production of urban space.

Small builders in Londrina have emerged at the moment that housing production advances towards a process of forming oligopolies through large constructors and incorporated companies (Fix, 2011). This process is a consequence of the implementation of a specific legislation (SFI), which allowed, among other things, large constructors and incorporated companies to increase their activities by opening their capital in the Stock Exchange, generating resources for new investments in the larger Brazilian cities that had suitable conditions both in terms of market and consumer income. In this context, international capital entered the Brazilian market of constructors and incorporated companies acquiring national companies and establishing control over their capital. 
Nonetheless, if the action of large constructors and incorporated companies controls a large proportion of the supply of housing in Brazil, how is it that the provision of houses by numerous builders, each having small amounts of capital for investment also expands?

The first element lies in the fact that these constructors have identified a market niche for their action. According to Oliveira (2011), circuit theory (Santos, 1979) indicates that one of the gaps that those with little capital can insert themselves into in this type of activity is the creation of consumer bases not served by the oligopolies. Due to their needs in terms of profit margins, the intensive nature of their capital, etc., these companies abandon certain market segments which are not profitable for them. Thus in an unequal and combined way the formation of oligopolies encourages the emergence of their opposite; the presence of small companies and small capital.

In other terms, the supply of housing between 1995 and 2003 was focused particularly on the supply of housing complex by the State and the private sector for those consumers with a higher purchasing power, through bank mortgages at high interest rates. From this perspective there was an economic segment for which there was no housing supply compatible with their income. It was at this time that the small constructor started to offer housing. From 2003 onwards, with the improvement in the offer of finance for home ownership, the small builders expanded their activities, which increased even further with the PMCMV. For a range of personal and economic reasons, this economic group, which reaches up to five or six minimum wages, does not wish to live in housing complex or apartments. Having identified this market, the small builder exploits the demand for housing.

The second element is linked to the matter of the offer of bank mortgages for the construction and acquisition of houses from 2003. It is important to point out that the offer of credit in a capitalist economy has a direct relationship with the development of that same society, as it allows productive investments and increases in income, employment and family consumption.

In Brazil the Credit/GDP relationship reduced from 35\% in June of 1994 to 22\% in October 2002 (Paula and Oreiro and Basilio, 2013). From then on it increased reaching 35.5\% in 2008 and $56.5 \%$ in 2013 (DIEESE, 2014). In this expansion the private banks had a greater participation until 2007, after which public banks have become the most important, as part of the Brazilian government's strategy to minimize the effects of the 2008 crisis.

One sector receiving strong investment was housing. This is part of what has been called directed credit, in which institutions are obliged to invest in determined ways according to regulations. Housing finance was $15.72 \%$ of total financing in 2008 and $32.75 \%$ in 2013 (DIEESE ,2014).

If housing credit had already been increasing since 2003, with the My House My Life Program this was further expanded with regulated interest rates. With this the housing credit for individuals was increased by $459 \%$ between 2008 and 2013 against $601 \%$ for companies in the same period. Thus, credit for the housing sector in relation to Brazil's GDP reached 8.22\% in 2013 against 1.84 in 2008 (DIEESE, 2014).

In these conditions the possibility for the growth in the property market becomes clear. Ever since the mid 1980s Brazil had not had an effective housing policy or such an expressive supply of credit as this. Therefore, while the small builders supplied few houses throughout the 1980s until 2003, from then on their activities expanded.

A third point is to locate the small builder in the production of the urban. This expression refers to the production of the city as a materialization of the social relationships of capitalist production and its relationships (Corrêa, 1989, 2011; Carlos 2008; Harvey 1980; Topalov 1979; Lefebvre 1999) among others.

It is important to emphasize that the agents who produce urban space - industrials, landowners, property promoters, the state and excluded groups- are considered by Corrêa (1989) as ideal types for the Brazilian context, a typology which offers a starting point (Corrêa, 2011). If these types are the most emphasized in the literature due to their effective participation in the production of urban 
space, then it is necessary to explore property promoters a little more as the small builders at the end of the $20^{\text {th }}$ and start of the $21^{\text {st }}$ century are included in this type.

It is noteworthy that Corrêa $(1989$, p. 20) had already drawn attention to the fact that different concrete types are inserted among property promoters "including the constructor-owner of the land, a classical agent who still persists, producing few and small properties." However, there are some differences between the small builder and the constructor owner, as the former buys land to build houses, and while each individual only builds a few properties during the course of a year, the collective group of small builders accounted for $9 \%$ of the residential total in Londrina between 2003 and 2013, under the category of apartments and homes with more than $80 \mathrm{~m}^{2}$.

For this reason the small builder should be considered an important agent in the context studied and also in other cities in different regions, being regarded as a segment of the property promoters. Therefore:

. The small builder is a concrete social agent in the production of urban space, producing the housing product for its commercialization, inserting it in capitalist circulation;

. In the specific act of production, the small builder does this based on capitalist social relationships, such as the payment of wages, with or without legal registration, evidencing the acquisition of surplus value;

. In the production of the house itself- which means capital- there is also the use of unsalaried labor denoting distinct processes in terms of social relationships and capitalist gain;

- This reproduces capitalist social relationships through the private ownership of land, extracting land income;

- The administrative cost is low, as it carried out by the builder themselves without payment;

- The available capital is small and the scale of action is restricted;

- The strategies of small builders for their activities are diversified but do not result in spatial alterations, as they do not produce new commercial centers, they do not control the market for land, etc.; however they have contributed to reduce the number of urban spaces which have not been built upon;

- Through their knowledge of their activity, their work, their strategies and particularly the price paid for the land, they have managed to create a product with a lower price than if it had been built by the large constructors or incorporated companies, be it in the expansive or recessionary phases of the national economy;

- It is of no little importance that individual builders reinvest their profits and income at a local level, strengthening part of the urban economy.

\section{FINAL CONSIDERATIONS}

The production of urban space continues to be complex, with growth both in terms of the segmentation of agents and the diversity of properties being offered in the recent period. The small builder of houses is an agent who produces urban space and yet there is still a limited literature discussing their action and importance.

What is the importance of discussing this agent for the understanding of the production of urban space? If studying the most emphasized agents in the literature allows the discovery of strategies and practices in the production of Brazilian cities through their dominance, the small builders have acquired an important role through their contribution. 
What is their contribution in terms of area and number of units in different Brazilian cities? What are their strategies and spatial practices? Can such agents continue acting in phases of economic contraction? Will there be a consumer market for their activity? Will the advance of production by oligopolies in terms of large constructors and incorporated companies affect their activity? These are some questions which encourage further research.

\section{ACKNOWLEDGEMENTS}

To Profs. Edilson Luis de Oliveira and Paulo Adeildo Lopes for their suggestions and criticisms.

\section{BIBLIOGRAPHIC REFERENCE}

ABADE, Fernando F. Diretrizes para aprovação de projetos - Londrina - PR. 2014. Monografia (Conclusão de Curso em Engenharia Civil) - Unifil, Londrina.

ALMEIDA, Roberto S. Alternativas da promoção imobiliária em grandes centros urbanos: o exemplo do Rio de Janeiro. In: VALLADARES, L. do P. (Org.). Repensando a habitação no Brasil. Rio de Janeiro: Zahar, 1983, p. 169-199.

AZEVEDO, S. de; RIBEIRO, L.C. de Q.(Org.). A crise da moradia nas grandes cidades: da questão da habitação à reforma urbana. Rio de Janeiro: Editora UFRJ, 1996.

BRASIL. Decreto no 90.922 de 6 de fevereiro de 1985. Regulamenta a Lei n ${ }^{0} 5.524$, de 05 de novembro de 1968, que dispõe sobre o exercício da profissão de técnico industrial e técnico agrícola de nível médio ou de $2^{\circ}$ grau. Disponível em: < http://www.planalto.gov.br/ccivil_03/decreto/antigos/d90922.htm >. Acesso em: julho 2015.

BRASIL. Lei Complementar n' 128 de 19 de Dezembro de 2008. Altera a Lei Complementar no 123, de 14 de dezembro de 2006, altera as Leis nos 8.212, de 24 de julho de 1991, 8.213, de 24 de julho de 1991, 10.406, de 10 de janeiro de 2002 - Código Civil, 8.029, de 12 de abril de 1990, e dá outras providências. Disponível em: < https://www.receita.fazenda.gov.br/legislacao/LeisComplementares/2008/leicp128.htm >. Acesso em: julho 2015.

BRASIL. MINISTÉRIO DO TRABALHO E EMPREGO. Base estatística RAIS: relação anual de informações sociais, 2013. Brasília, 2013.

BRASIL. Comitê gestor aprova consolidação normativa do simples nacional e regulamenta Lei Complementar no 139/2011. Disponível em: < http://www.receita.fazenda.gov.br/automaticoSRFSinot/2011/12/02/2011_12_02_16_25_42_56841797.html >. Acesso em: julho 2015.

CAMARA BRASILEIRA DA INDÚSTRIA DA CONSTRUÇÃO. Pib Brasil e construção civil. Disponível em: < http://www.cbicdados.com.br/menu/pib-e-investimento/pib-brasil-e-construcao-civil >. Acesso em: junho 2015.

CAMPOS, H. A; SILVEIRA, R. L. da. BERGAMASCHI, E.; FROHLICH, C. P.; SILVEIRA, R. C. E. Agentes sociais urbanos, estratégias de ação e seus reflexos na organização espacial das cidades de Santa Cruz do Sul e Lajeado. In: Campos, H. A.; SILVEIRA, R. L. L. Valorização do solo e reestruturação urbana: os novos produtos imobiliários na Região dos Vales - RS. Santa Cruz do Sul : EDUNISC, 2014. Disponível em: www.unisc.br/edunisc. Acesso em: maio 2015.

CARDOSO, Adauto (Org.). O programa minha casa minha vida e seus efeitos territoriais. Rio de Janeiro: Letra Capital, 2013.

CARLOS, A. F. A. A (re) produção do espaço urbano. 2. ed. São Paulo: EDUSP, 2008. 272p.

CASARIL, C. C. Meio século de verticalização urbana em Londrina-PR e sua distribuição espacial: 1950-2000. 2008. Dissertação (Mestrado em Geografia) - UEL, Londrina.

CONSELHO FEDERAL DE ENGENHARIAARQUITETURA E AGRONOMIA. Resolução nº $\mathbf{2 6 2}$, de 28 de julho de 1979. Dispõe sobre as atribuições dos Técnicos de $2^{\circ}$ grau, nas áreas da engenharia, arquitetura e agronomia. Disponível em: <http://normativos.confea.org.br/downloads/0262-79.pdf >. Acesso em: julho 2015. 
CONSELHO FEDERAL DE ENGENHARIA ARQUITETURA E AGRONOMIA. Resolução no 278, de 27 de maio de 1983. Dispõe sobre o exercício profissional dos Técnicos Industriais e Técnicos Agrícolas de Nível Médio ou de $2^{\circ}$ Grau e dá outras providências. Disponível em: < http://normativos.confea.org.br/ ementas/visualiza.asp?idEmenta=326 > . Acesso em: julho 2015.

CORRÊA, R. L. O espaço urbano. São Paulo: Ática, 1989.

CORREAA, R. L. sobre agentes sociais, escala e produção do espaço: um texto para discussão. In: CARLOS, A. F. A.; SOUZA, M. L.; SPOSITO, M. E. (Org.). A produção do espaço urbano: agentes, processos, escalas e desafios. São Paulo: Contexto, 2011, p. 41-51.

CREA - PR. Programa Casa Fácil. Disponível em: $<$ http://www.crea-pr.org.br/index.php?option=com content\&view $=$ article $\& i d=3232$ : crea-promove-forum-estadual-do-programa-casa-facil-em-londrina\&catid=3:newsflash >. Acesso em: junho 2015.

DIEESE. A evolução do crédito na economia brasileira: 2008-2013. Nota Técnica, São Paulo, n. 135, p. 1-31. Disponível em: < http://www.dieese.org.br/notatecnica/2014/notaTec135Credito.pdf >. Acesso em: julho 2015.

FERREIRA, João S. Whitaker (Coord.). Produzir casas ou construir cidades? desafios para um novo Brasil urbano: parâmetros de qualidade para a implementação de projetos habitacionais e urbanos. São Paulo: Editora FUPAM, 2012.

FIX, Mariana A. B. Financeirização e transformações recentes no circuito imobiliário no Brasil. 2011. Tese (Doutorado em Economia) - Instituto de Economia, Unicamp, Campinas, 2011.

GONÇALVES, J. S. Circuito pecuária do "boi que como floresta" e a reprodução da lógica de acumulação primitiva nos cercamentos da fronteira amazônica: uma discussão sobre a especulação financeira e a riqueza patrimonial. CIRCUITO DE DEBATES ACADÊMICOS - CODE, 2011. Anais..., P. 1-17. Brasília, IPEA, 2011.

HARVEY, D. A justiça social e a cidade. São Paulo: Hucitec, 1980.

IBGE. Produto interno bruto dos municípios: 2003-2007. IBGE: Rio de Janeiro, 2009. Disponível em: http://www.ibge.gov.br/home/estatistica/economia/pibmunicipios/2003_2007/PIB_2003_2007.pdf. Acesso em: julho 2015.

IBGE. Pib per capita Brasil: 2008 - 2014. Disponível em: <http://brasilemsintese.ibge.gov.br/pt/contas-nacionais/pib-per-capita>. Acesso em: julho 2015.

IBGE. Produto interno bruto dos municípios 2012. Rio de Janeiro: IBGE, 2015. Disponível em: http:// biblioteca.ibge.gov.br/biblioteca-catalogo?view=detalhes\&id=291152 >. Acesso em 05 de julho de 2015.

IBGE. Censo demográfico 2010. Rio de Janeiro: IBGE, 2010. Disponível em: $<$ http://www.ibge.gov.br/ home/estatistica/populacao/censo2010/resultados_preliminares/preliminar_tab_municipio_zip.shtm >. Acesso em: junho 2015.

IBGE. Contas nacionais trimestrais: indicadores de volumes e valores correntes: 2o trimestre de 2013. Disponível em: < http://www.ibge.gov.br/home/presidencia/noticias/imprensa/ppts/000000144950081320 13502830816470.pdf $>$. Acesso em: julho 2015.

LEFEBVRE, H. A cidade do capital. Rio de Janeiro: DP\&A Editora, 1999.

LIMONAD, E., BARBOSA, J. L. Entre o ideal e o real rumo a sociedade urbana: algumas considerações sobre o "Estatuto da Cidade". Geousp, São Paulo, v. 13, n. 1, p. 87-106, 2003.

LONDRINA, Prefeitura Municipal. Perfil do município de Londrina - 2014 ( ano base 2013). Londrina: Prefeitura Municipal, 2014. Disponível em: <http://www.londrina.pr.gov.br/dados/images/stories/Storage/ sec_planejamento/perfil/perfil_final_2014.pdf $>$. Acesso em: julho 2015.

LONDRINA, Prefeitura Municipal. Secretaria de Obras. Relatório da diretoria de aprovações: 2003-2013. Londrina: Prefeitura Municipal, 2015.

LOPES, P. A. Condomínios horizontais e loteamentos fechados: uma metodologia de avaliação de desempenho de ambientes coletivos a partir do caso de Londrina - PR. 2005. Tese (Doutorado em Arquitetura e Urbanismo) - FAU/USP, São Paulo. 
NASCIMENTO, C. F. Verticalização de Londrina - PR: financeirização e mercado imobiliário entre 20002013. 2015. Dissertação (Mestrado em Geografia) - UEL, Londrina.

OLIVEIRA, Edilson Luis de. Divisão do trabalho e circuitos da economia urbana. Londrina: Eduel, 2011. PAULA, Luiz Fernando de; OREIRO, José Luis; BASILIO, Flavio A. C. Estrutura do setor bancário e o ciclo recente de expansão do crédito: o papel dos bancos públicos federais. Nova Economia, Belo Horizonte, v. 23, n. 3, dec. 2013, p. 473-520.

PASSOS, V. R. L. A verticalização de Londrina: 1970/2000: a ação dos promotores imobiliários. 2007. Dissertação (Mestrado em Geografia) - UEL, Londrina.

PORTAL BRASIL. Taxas desemprego 2003 - 2012. Disponível em: $<$ http://www.brasil.gov.br/economia-e-emprego/2013/01/pais-fecha-2012-com-menor-taxa-de-desemprego >. Acesso em: julho de 2015.

RANGEL, I. Obras reunidas. Rio de Janeiro: Contraponto, 2005

RIBEIRO, Luis C. de Q. A formação do capital de incorporação: trajetória histórica da habitação no Rio de Janeiro. ENCONTRO NACIONAL DA ANPUR, 4, 1991. Anais... Salvador, 1991.

SANTOS, Milton. O espaço dividido: os dois circuitos da economia urbana dos países subdesenvolvidos. Rio de Janeiro: Francisco Alves, 1979.

SHIMBO, Lúcia Zanin. Habitação social, habitação de mercado: a confluência entre estado, empresas construtoras e capital financeiro. 2010. Tese ( Doutorado em Engenharia) - São Carlos, Escola de Engenharia da Universidade de São Carlos/USP, 2010.

SUMMA, Ricardo. Mercado de trabalho e a evolução dos salários no Brasil. Texto para Discussão, Rio de Janeiro, n. 13, 2014. Instituto de Economia: UFRJ. Disponível em: < http://www.ie.ufrj.br/images/pesquisa/ publicacoes/discussao/2014/TD_IE_013_2014_SUMMA.pdf > . Acesso em: julho 2015.

TOPALOV, C. La urbanización capitalista: algunos elementos para su analise. México: Edical, 1979.

ZACCHI, Raquel C. O espaço urbano da cidade capitalista: um estudo sobre o processo de verticalização da área central da cidade de Viçosa (MG) (1970-2007). Brazilian Geographical Journal: Geosciences and Humanities research medium, Ituiutaba, v. 5, n. 2, p. 352-370, jul./dec. 2014.

Submitted december 2015 Accepted january 2016 